\title{
Anti-inflammatory effects of Phyllanthus amarus Schum. \& Thonn. through inhibition of NF-KB, MAPK, and PI3K-Akt signaling pathways in LPS-induced human macrophages
}

\author{
Hemavathy Harikrishnan ${ }^{1}$, Ibrahim Jantan ${ }^{1,2^{*}}$, Md. Areeful Haque ${ }^{1}$ and Endang Kumolosasi ${ }^{1}$
}

\begin{abstract}
Background: Phyllanthus amarus has been used widely in various traditional medicines to treat swelling, sores, jaundice, inflammatory diseases, kidney disorders, diabetes and viral hepatitis, while its pharmacological and biochemical mechanisms underlying its anti-inflammatory properties have not been well investigated. The present study was carried out to investigate the effects of $80 \%$ ethanolic extract of $P$. amarus on pro-inflammatory mediators release in nuclear factor-kappa B (NF-kB), mitogen activated protein kinase (MAPK) and phosphatidylinositol 3-kinase/Akt (PI3K-Akt) signaling activation in lipopolysaccharide (LPS)-induced U937 human macrophages.

Methods: The release of prostaglandin $\mathrm{E}_{2}\left(\mathrm{PGE}_{2}\right)$ and pro-inflammatory cytokines, tumor necrosis factor (TNF)- $a$ and interleukin (IL)-1 $\beta$ in a culture supernatant was determined by ELISA. Determination of cyclooxygenase-2 (COX-2) protein and the activation of MAPKs molecules (JNK, ERK and p38 MAPK), NF-KB and Akt in LPS-induced U937 human macrophages were investigated by immunoblot technique. The relative gene expression levels of COX-2 and proinflammatory cytokines were measured by using qRT-PCR. The major metabolites of $P$. amarus were qualitatively and quantitatively analyzed in the extract by using validated reversed-phase high performance liquid chromatography (HPLC) methods.

Results: P. amarus extract significantly inhibited the production of pro-inflammatory mediators (TNF- $\alpha, I L-1 \beta, P G E_{2}$ ) and COX-2 protein expression in LPS-induced U937 human macrophages. P. amarus-pretreatment also significantly downregulated the increased mRNA transcription of pro-inflammatory markers (TNF- $\alpha, \mathrm{IL}-1 \beta$, and COX-2) in respective LPS-induced U937 macrophages. It downregulated the phosphorylation of NF-KB (p65), IKBa, and IKKa/ $\beta$ and restored the degradation of $\mathrm{IKBa}$, and attenuated the expression of Akt, JNK, ERK, and p38 MAPKs phosphorylation in a dosedependent manner. P. amarus extract also downregulated the expression of upstream signaling molecules, TLR4 and MyD88, which play major role in activation of NF-KB, MAPK and PI3K-Akt signaling pathways. The quantitative amounts of lignans, phyllanthin, hypophyllahtin and niranthin, and polyphenols, gallic acid, geraniin, corilagin, and ellagic acid in the extract were determined by HPLC analysis.
\end{abstract}

Conclusion: The study revealed that P. amarus targeted the NF-KB, MAPK and PI3K-Akt signaling pathways to exert its anti- inflammatory effects by downregulating the prospective inflammatory signaling mediators.

Keywords: Phyllanthus amarus, Macrophages, Inflammation, Cytokines, NF-KB, MAPK, PI3K-Akt

\footnotetext{
* Correspondence: profibj@gmail.com

${ }^{1}$ Drug and Herbal Research Center, Faculty of Pharmacy, Universiti

Kebangsaan Malaysia, Jalan Raja Muda Abdul Aziz, 50300 Kuala Lumpur,

Malaysia

${ }^{2}$ School of Pharmacy, Taylor's University, Lakeside Campus, 47500 Subang

Jaya, Selangor, Malaysia
}

(c) The Author(s). 2018 Open Access This article is distributed under the terms of the Creative Commons Attribution 4.0 International License (http://creativecommons.org/licenses/by/4.0/), which permits unrestricted use, distribution, and reproduction in any medium, provided you give appropriate credit to the original author(s) and the source, provide a link to the Creative Commons license, and indicate if changes were made. The Creative Commons Public Domain Dedication waiver (http://creativecommons.org/publicdomain/zero/1.0/) applies to the data made available in this article, unless otherwise stated. 


\section{Background}

Inflammation is an innate immune response occurring in our body to protect against harmful chemicals and invading pathogens. During inflammation, macrophages which reside in tissues and organs of human body are activated by infectious materials or injury. The activated macrophages will produce inflammatory mediators such as nitric oxide $(\mathrm{NO})$, prostaglandin $\mathrm{E}_{2}$ $\left(\mathrm{PGE}_{2}\right)$, interleukin 1 beta $(\mathrm{IL}-1 \beta)$ and tumor necrosis factor (TNF- $\alpha$ ), to defend against the invading pathogens $[1,2]$. The occurrence of prolonged inflammatory response will lead to the development of various chronic diseases such as rheumatoid arthritis, chronic hepatitis, atherosclerosis, cancer, and inflammatory brain diseases [3-5].

Lipopolysaccharide (LPS) is a bacterial endotoxin, which activates the TLR4 receptors on macrophage and stimulates the recruitment of cytoplasmic MyD88 and TRIF adaptor proteins. The binding of the adaptor proteins on TLR4 complex will trigger the activation of nuclear factor- $\mathrm{B}(\mathrm{NF}-\kappa \mathrm{B})$ and mitogen activated protein kinase (MAPK) pathways [2]. However, NF- $\mathrm{B}$ is an ubiquitous nuclear transcription factor, regulates the expression of various genes which play pivotal roles in inflammation, autoimmune diseases, apoptosis and carcinogenesis [6]. In a resting cell, the NF-kB which consists of p50/p65 heterodimer bound to the inhibitory protein IкBs and remain inactive in cytoplasm. In response to LPS stimulation, activated IkB kinases (IKKs) will phosphorylate two specific serine residues (Ser32 and Ser36) on IkBs leading to its degradation through the ubiquitination and proteolysis by the $26 \mathrm{~S}$ proteasome $[2,7,8]$. The resulting free $\mathrm{NF}-\mathrm{kB}$ in cytoplasm will translocate into nucleus and binds to the specific $I \kappa B$ binding sites in the promoter region of target genes, followed by the transcription of various inflammatory mediators $[1,9,10]$. On the other hand, the MAPKs family consists of three major classes, extracellular signal-regulated kinases 1 and 2 (ERK1/2), c-Jun N-terminal kinase (JNK) and p38. The phosphorylation of the MAPKs in LPS-induced macrophages will trigger the transcriptional activation of NF-kB [2]. Both NF- $\mathrm{kB}$ and MAPK pathways will work together to aggravate the inflammatory diseases in LPS-induced inflammation models $[11,12]$. The uncontrolled activation of NF- $\mathrm{KB}$ and MAPK signaling pathways will cause detrimental effects to the living organisms. Recent studies have found that the phosphatidylinositol 3-kinase/Akt (PI3K-Akt) signaling pathway was responsible for the expression of pro-inflammatory markers through the $I \kappa B$ degradation and NF- $\kappa B$ activation in LPS induced cells. Hence, targeting these signaling pathways will be an attractive therapeutic approach for the development of anti-inflammatory drugs [13].
Currently, non-steroidal anti-inflammatory drugs (NSAIDs) such as aspirin and ibuprofen are available to treat inflammatory diseases by inhibiting cyclooxygenase-2(COX-2) activation. However, they possess adverse effects, which include disturbance in upper gastrointestinal system and heartburn which limit their use [14]. Therefore, many researchers are trying to find a drug with greater efficacy and minimal toxicity to treat the inflammatory related diseases [15]. Phyllanthus amarus Schum. \& Thonn. (Family: Euphorbiaceae) is a medicinal herb which is widely distributed in tropical and subtropical countries from Africa to Asia, South America and the West Indies [16]. P. amarus has been reported to have an array of ethanopharmacological activities such as anti-inflammatory, hepatoprotective, nephroprotective, anti-amnesia, anti-cancer, diuretic, antioxidant, anti-viral, anti-bacterial, anti-hyperglycemic, antihypercholesterolemia and so on [17-19]. The plant is a rich source of secondary metabolites such as alkaloids, flavonoids, hydrolysable tannins, lignans, polyphenols, triterpenes, sterols and volatile oils [20-23]. The anti-inflammatory activities of $P$. amarus have been demonstrated in rat models of carrageenan-induced rat paw edema air-pouch inflammation and cotton pellet granuloma [24]. Several lignans isolated from $P$. amarus such as niranthin, nirtetralin and phyltetralin exhibited in vitro and in vivo anti-inflammatory activities [25]. Previously we have reported the in vitro inhibitory effects of $P$. amarus and its isolates on phagocytic activity of human neutrophils and NO production, lymphocyte proliferation and cytokine release from phagocytes [26, 27]. Immunosuppressive effects of the standardized extract of $P$. amarus on cellular and humoral immune responses in Balb/C mice and Wistar-Kyoto rats have also been investigated [28, 29]. Despite its various pharmacological activities, there is no comprehensive investigation on molecular mechanisms underlying the anti-inflammatory effects of $P$. amarus extract in human macrophages. Hence, the present study was conducted to investigate the effects of $80 \%$ ethanolic extract of $P$. amarus on the production of pro-inflammatory mediators and the activation of signaling molecules related to NF-kB, MAPK and PI3K-Akt signaling pathways.

\section{Methods}

\section{Chemicals and reagents}

Roswell Park Memorial Institute (RPMI) 1640 medium, penicillin-streptomycin (Pen Strep), fetal bovine serum (FBS) were purchased from Gibco (Grand Island, NY, USA). Phorbol 12-myristate 13-acetate (PMA), LPS (Escherichia coli 055:B5), RIPA buffer, DMSO were purchased from Sigma Chemical Co. (St. Louis, MO, USA). 1× Halt Protease and Phosphatase Inhibitor Cocktail was purchased from Pierce (Rockford, IL, USA). Human 
TNF- $\alpha$ and IL-1 $\beta$ enzyme-linked immunosorbent assay (ELISA) kits were purchased from R\&D Systems (Minneapolis, MN, USA). Alamar blue reagent for cell viability assay was purchased from Life Technologies (Grand Island, NY, USA). Primary antibodies specific to COX-2, p-p38, p38, p-ERK1/2, ERK1/2, p-JNK1/2, JNK1/2, p-IкB $\alpha$, IкB $\alpha, p-I K K \alpha / \beta, p-N F \kappa B p 65$ and $\beta$-actin were purchased from Cell Signaling Technology (Beverly, MA) and, in addition, anti-rabbit secondary antibody conjugated to horseradish peroxidase was obtained from Cell Signaling Technology (Beverly, MA). Methanol and acetonitrile of HPLC grade were purchased from Fisher Scientific (Loughborough, UK). Phyllanthin, hypophyllanthin, niranthin gallic acid, ellagic acid, corilagin and geraniin (purity > 98\%) were purchased from ChromaDex (CA, USA). Dexamethasone was obtained from CCM Duopharma Biotech Bhd (Selangor, Malaysia).

\section{Preparation of $P$. amarus ethanol extract}

The whole plants of $P$. amarus were collected from Marang, Kuala Terengganu, Malaysia, in February 2015. The plant was authenticated by Dr. Abdul Latif Mohamad of Faculty of Science and Technology, Universiti Kebangsaan Malaysia (UKM). A voucher specimen (voucher number UKMB 30075) has been deposited at the Herbarium of UKM, Bangi, Malaysia for future reference. The plant materials were dried at room temperature and powdered. The powdered plant material was macerated with $80 \%$ ethanol for $72 \mathrm{~h}$ and the crude ethanol extract was filtered through Whatmann No 1 filter paper. The filtrate was solvent-evaporated using rotary evaporator, freeze dried and stored in an airtight container for further investigation.

\section{High performance liquid chromatography analysis}

Qualitative and quantitative high performance liquid chromatography (HPLC) analysis of the $80 \%$ ethanolic extract of $P$. amarus was carried out according to the method of Jantan et al. with slight modification [27]. These stock solutions $(20 \mathrm{mg} / \mathrm{mL})$ were sonicated for $15 \mathrm{~min}$ and filtered through $0.45 \mu \mathrm{m}$ Millipore Millex PTFE membranes (Maidstone, Kent, UK). The solutions for reference standards (phyllanthin, hypophyllanthin, niranthin, gallic acid, ellagic acid, corilagin and geraniin) were prepared at a concentration of $1 \mathrm{mg} / \mathrm{mL}$ and further diluted into a series of concentration (1000-125 $\mu \mathrm{g} / \mathrm{mL})$. The HPLC analysis was performed on a Waters 2535 Quaternary Gradient Module equipped with PDA Photodiode Array Detector (Waters 2998) of wavelength ranging from 205 to $270 \mathrm{~nm}$ and data were acquired by using Empower 3 software. The chromatographic analysis was performed on an XBridge ${ }^{\text {Tis }}$ C-18 (250 mm length $\times 4.6 \mathrm{~mm}$ i.d., $5 \mu \mathrm{m}$ ) analytical column (Waters, Milford, MA, USA). Analysis of the extracts and standard solutions of lignans (phyllanthin, hypophyllanthin, niranthin) followed the following parameter: isocratic elution with solvent A. acetonitrile: solvent B. water (acidified with $0.1 \%$ orthophosphoric acid) (55:45) as mobile phase at a flow rate of $1.0 \mathrm{~mL} / \mathrm{min}$. The column was maintained at $25{ }^{\circ} \mathrm{C}$ and the detection wavelength was $205 \mathrm{nM}$. The identification and quantification of the polyphenols (geraniin, corilagin, ellagic acid and gallic acid) in the $80 \%$ ethanolic extract of $P$. amarus were carried out based on the chromatographic condition as follows: gradient elution with acetonitrile and $0.2 \%$ orthophosphoric acid as mobile phase at a flow rate of $1.0 \mathrm{~mL} / \mathrm{min}$. Quantification of compounds in the extracts was based on the standard curves equations obtained by plotting calibration curves of five concentrations $(1000-125 \mu \mathrm{g} / \mathrm{mL})$ each of the standard solution of compounds versus the areas under the peaks.

\section{Validation procedures for HPLC analysis}

The HPLC method was validated by determining the linearity, precision, limits of quantification (LOQ) and detection (LOD). The precision of the method was determined by studying intra-day and inter-day variations. Separately one concentration of extracts $(20 \mathrm{mg} / \mathrm{mL})$ and reference compounds $(125,500,1000 \mu \mathrm{g} / \mathrm{mL})$ were injected three times for each concentration in one day and on three different days. The calibration curve was obtained by using phyllanthin, hypophyllanthin and niranthin as external standards. Six concentrations of each standard $(31.25-1000 \mu \mathrm{g} / \mathrm{mL})$ were injected in triplicate, and the curve was constructed by plotting the corresponding peak areas versus the concentration of each standard. The linearity was evaluated by linear calibration analysis while the correlation coefficient $\left(R^{2}\right)$ was calculated from the calibration curves. LOD and LOQ were calculated from RSD and slope (S) of the calibration curves by using following equations: $\mathrm{LOD}=3.3 \times(\mathrm{RSD} / \mathrm{S})$ and $\mathrm{LOQ}=10 \times(\mathrm{RSD} / \mathrm{S})$.

\section{LC-MS analysis}

LC-MS analysis was performed onThermo Scientific C18 column (AcclaimTM Polar Advantage II, $3 \times 150 \mathrm{~mm}$, $3 \mu \mathrm{m}$ particle size) on an UltiMate 3000 UHPLC system (Dionex). The LC-MS was carried out by using the gradient program at $0.4 \mathrm{~mL} / \mathrm{min}, 40{ }^{\circ} \mathrm{C}$ using $\mathrm{H}_{2} \mathrm{O}+0.1 \%$ Formic Acid (A) and 100\% ACN (B) with 22 min total run time with sample injection volume of $1 \mathrm{uL}$. Gradient started at 5\% B (0-3 min); 80\% B (3-10 min); 80\% B (10-15 $\mathrm{min})$ and $5 \% \mathrm{~B}(15-22 \mathrm{~min})$. The positive and negative ionization spectra obtained with MicroTOF QIII Bruker Daltonic with the following settings:- capillary voltage: $4500 \mathrm{~V}$; nebulizer pressure: 1.2 bar; drying gas: $8 \mathrm{~L} / \mathrm{min}$ at $200{ }^{\circ} \mathrm{C}$. The mass range was at $50-1000 \mathrm{~m} / \mathrm{z}$. The accurate mass data of the molecular ions, provided by 
the TOF analyzer, were processed by Compass Data Analysis software (Bruker Daltonik $\mathrm{GmbH}$ ). The corresponding peaks of the compounds were identified by comparison with the mass spectral library.

\section{Cell culture and differentiation induction}

U937 (ATCC ${ }^{\bullet}$ CRL-1593.2) cell line was obtained from ATCC (American Type Culture Collection). U937 mononuclear cell line was grown in RPMI 1640 medium supplemented with $10 \%(v / v)$ fetal bovine serum (FBS) and $1 \%(\mathrm{v} / \mathrm{v})$ penicillin $\mathrm{G} /$ streptomycin at $37{ }^{\circ} \mathrm{C}$ under $5 \% \mathrm{CO}_{2}$. The U937 cells density was maintained between $1 \times 10^{5}$ and $2 \times 10^{6}$ viable cells $/ \mathrm{mL}$ throughout the experiments. Cells were harvested once the cell confluency reached approximately $80-90 \%$. For all the experiments, the U937 cells were differentiated to obtain macrophage like phenotype by addition of phorbol 12-myristate 13-acetate (PMA) (Sigma-Aldrich) at $200 \mathrm{nM}$, for $24 \mathrm{~h}$. The following day, cells were washed with complete culture media once and incubated overnight with serum free media for recovery phase $[1,30]$.

\section{Alamar blue for testing cell viability}

The cell viability assay was carried out with Alamar blue reagent according to the manufacturer standard protocol to determine the cytotoxicity effect induced by the $80 \%$ ethanolic extract of $P$. amarus. The differentiated macrophages were plated at a density $5 \times 10^{5}$ cells $/ \mathrm{mL}$ onto 96 well plate. $P$. amarus extract was dissolved in DMSO, and the DMSO concentration did not exceed $1 \%$. The cells were treated with various concentrations of $P$. amarus extract of serial dilutions $60,30,15,7.5$, and $3.25 \mu \mathrm{g} / \mathrm{mL}$ and then incubated for $24 \mathrm{~h}$. After $24 \mathrm{~h}$ of incubation, $10 \% v / \mathrm{v}$ of $10 \mathrm{x}$ Alamar blue cell viability reagents was added into each well followed by $4 \mathrm{~h}$ incubation at $37{ }^{\circ} \mathrm{C}, 5 \% \mathrm{CO}_{2}$ incubator. Then the reduction of an active compound of Alamar blue, resazurin into resorufin by viable cells was read with Tecan plate reader at $570 \mathrm{~nm}$ using $600 \mathrm{~nm}$ (normalized to $600 \mathrm{~nm}$ value) as a reference wavelength. The results were expressed as percentage of viable cells over control cells [19].

\section{Enzyme-linked immunosorbent assay}

To investigate the effect of $P$. amarus extract on cytokines levels from LPS-induced cells, differentiated U937 macrophages $\left(5 \times 10^{5}\right.$ cells $\left./ \mathrm{mL}\right)$ seeded into 24 well plate were pretreated with $60,30,15,7.5$ and $3.75 \mu \mathrm{g} / \mathrm{mL}$ of $P$. amarus extract or with $4,0.4,0.04,0.004$ and $0.0004 \mu \mathrm{g} / \mathrm{mL}$ of dexamethasone for $2 \mathrm{~h}$ prior to $24 \mathrm{~h}$ stimulation with $1 \mu \mathrm{g} / \mathrm{mL}$ LPS. In another experiment, the differentiated cells also pretreated with SB202190 (a p38 inhibitor, $10 \mu \mathrm{M}$ ), U0126 (an ERK inhibitor, $10 \mu \mathrm{M}$ ), SP600125 (a JNK inhibitor, $10 \mu \mathrm{M}$ ), BAY 11-7082 (an NF-kB inhibitor, $10 \mu \mathrm{M}$ ) and LY294002 (an Akt inhibitor,
$10 \mu \mathrm{M})$ for $2 \mathrm{~h}$ and then cultured with LPS of $1 \mu \mathrm{g} / \mathrm{mL}$ for $24 \mathrm{~h}$ to study the effect of inhibitors on TNF- $\alpha$ release. The U937 macrophages untreated with LPS which acted as a control was included for comparison. After $24 \mathrm{~h}$, the cell free supernatants were collected and stored at $-20{ }^{\circ} \mathrm{C}$ until cytokine analysis. The concentrations of TNF- $\alpha$ and IL-1 $\beta$ in the supernatants of U937 cell cultures were determined using DuoSet ${ }^{\circ}$ ELISA Development System (R\&D Systems, Minneapolis, MN, USA) kit according to the manufacturer protocol $[1,19]$.

\section{Measurement of $\mathrm{PGE}_{2}$}

The differentiated U937 cells were plated in a 24 well plate and pretreated with concentrations of $P$. amarus $(60,30$ and $15 \mu \mathrm{g} / \mathrm{mL})$ for $2 \mathrm{~h}$ and then stimulated with $1 \mu \mathrm{g} / \mathrm{mL}$ of LPS for $24 \mathrm{~h}$. The supernatants were assayed to determine the $\mathrm{PGE}_{2}$ level. The $\mathrm{PGE}_{2}$ level was analyzed by using ELISA kit (R\&D Systems, Minneapolis, MN, USA) according to manufactures protocol $[1,19]$.

Quantification of relative gene expression level by qRT-PCR U937 macrophages $\left(1 \times 10^{6}\right.$ cells $\left./ \mathrm{mL}\right)$ were pre-treated with varying concentrations of $P$. amarus $(60,30$, and $15 \mu \mathrm{g} / \mathrm{mL}$ ) for $2 \mathrm{~h}$ and later cultured with LPS of $1 \mu \mathrm{g} /$ $\mathrm{mL}$ for 1 day. The inhibitory properties of $P$. amarus on the expression of COX-2, TNF- $\alpha$, and IL- $1 \beta$ were evaluated by qRT-PCR $[1,19]$. To determine the gene expression level, total RNA was extracted from LPS treated U937 cells by using innuPREP RNAmini kit (Analytik Jena AG, Germany) and cDNA was synthesized by using SensiFAST ${ }^{\text {max }}$ cDNA Synthesis Kit (Bioline USA Inc., Taunton, MA) following manufacturer protocol. Quantification of mRNA by qRT-PCR was done using CFX96 Touch $^{\text {Tw }}$ Real-Time PCR Detection System (Biorad, Hercules, California, USA) along with SYBR ${ }^{\circ}$ Green RT-PCR Master Mix (Bioline USA Inc., Taunton, $\mathrm{MA})$. The cDNA was amplified by using the following primers; COX-2 (Hs_PTGS2_1_SG QuantiTect Primer QT00040586), TNF- $\alpha$ (Hs_TNF_3_SG QuantiTect Primer QT01079561), IL-1 $\beta$ (Hs_IL1B_1_SG QuantiTect Primer QT00021385) and GADPH (Hs_GAPDH_1_SG QuantiTect Primer QT00079247). The PCR reaction mixture consisted of $10 \mu \mathrm{L}$ of SYBR master mixture, $2 \mu \mathrm{L}$ of reverse and forward primers, $6 \mu \mathrm{L}$ of deionized water and $2 \mu \mathrm{L}$ of cDNA. The reaction was carried out in the following parameter: $95{ }^{\circ} \mathrm{C}$ for $2 \mathrm{~s}, 95{ }^{\circ} \mathrm{C}$ for $5 \mathrm{~min}, 60{ }^{\circ} \mathrm{C}$ for $10 \mathrm{~min}, 72{ }^{\circ} \mathrm{C}$ for $20 \mathrm{~min}$ (36 cycles). The relative fold difference between samples was determined following the comparative cycle threshold $\left(2^{-\Delta \Delta C t}\right)$ method. Glyceraldehyde 3-phosphate dehydrogenase (GADPH) was used as the housekeeping gene for normalizing the data. 


\section{Western blotting analysis}

Differentiated cells $\left(1 \times 10^{6}\right.$ cells $\left./ \mathrm{mL}\right)$ were plated onto six well plate and pretreated with $60,30,15 \mu \mathrm{g} / \mathrm{mL}$ of $P$. amarus extract, SB202190, U0126, SP600125, LY294002 and BAY 11-7082 $(10 \mu \mathrm{M})$ for $2 \mathrm{~h}$ and then stimulated with $1 \mu \mathrm{g} / \mathrm{mL}$ of LPS for $30 \mathrm{~min}$. The cells were harvested by centrifugation at $7000 \mathrm{xg}$ for $5 \mathrm{~min}$ and washed twice with ice cold PBS. The washed cell pellets were lysed in RIPA buffer and halt protease and phosphatase inhibitor cocktails. The cell lysates were centrifuged at 13,000 x $g$ for $10 \mathrm{~min}$ and protein concentrations were measured by Bradford assay. Approximately $20 \mu \mathrm{g}$ of proteins were resolved by $10 \%$ SDS-polyacrylamide gel electrophoresis and were electroblotted onto polyvinylidene difluoride (PVDF) membrane. The immunoblot was incubated for $1 \mathrm{~h}$ with $5 \%$ skim milk powder in TBS-T buffer containing $0.1 \%$ Tween 20 to block the nonspecific binding prior to the overnight incubation with specific primary antibodies that recognized COX-2, p-p38 (Thr180/Tyr182), p38, p-ERK1/2 (Thr202/Tyr204), ERK1/2, p-JNK1/2 (Thr183/ Tyr185), JNK1/2, p-ІкB $\alpha$ (Ser32/36), ІкB $\alpha, \quad$ p-IKK $\alpha / \beta$ (Ser176/180), p-NFkBp65 (Ser536), p-Akt (Ser 473) and $\beta$-actin (Cell Signaling Technology Inc., Beverly, MA). The following day, membrane was washed with TBS-T (0.1\% Tween 20) 3 times for $10 \mathrm{~min}$ each. It was then incubated with anti-rabbit secondary antibody conjugated to horseradish peroxidase for $1 \mathrm{~h}$ at room temperature with agitation and washed 3 times with TBST for $10 \mathrm{~min}$ each. Each protein band was detected using chemiluminescence detection system according to the manufacturer instruction. The band intensity was quantified using Image $\mathrm{Lab}^{\mathrm{Tu}}$ software $[1,2,31]$.

\section{Statistical analysis}

Statistical analyses were performed using the GraphPad Prism 6.0 (GraphPad Software, San Diego, CA, USA). For each experiment, three independent experiments were performed and data are expressed as mean \pm standard error mean (SEM). Differences between two means were analyzed by one-way analysis of variance (ANOVA) followed by post-hoc Dunnett's test with $P<0.05$ considered as statistically significant.

\section{Results}

Quantitative and qualitative analysis of $80 \%$ ethanolic extract of $P$. amarus

To identify and quantify the active components of $P$. amarus we performed HPLC analysis of the ethanol extract and several representative standards as previously reported by Jantan et al. [32]. Peaks with the same retention time as the standard compounds, phyllanthin (11.17 $\mathrm{min})$, hypophyllahtin (11.71 $\mathrm{min}$ ) and niranthin (14.48 min) were observed in P. amarus (Fig. 1a). For the polyphenols, four peaks were identified namely gallic acid (7.89 min), geraniin (23.76 min), corilagin (26.41 min) and ellagic acid (33.42 min) (Fig. 1b). Among the lignans, phyllanthin $(660.28 \mu \mathrm{g} / \mathrm{mL})$ was present at the highest concentration compared to niranthin $(575.11 \mu \mathrm{g} / \mathrm{mL})$ and hypophyllanthin $(290.46 \mu \mathrm{g} / \mathrm{mL})$. Among the identified polyphenols, ellagic acid $(601.29 \mu \mathrm{g} / \mathrm{mL})$ was the most abundant, followed by corilagin $(313.41 \mu \mathrm{g} / \mathrm{mL})$, geraniin $(170.49 \mu \mathrm{g} / \mathrm{mL})$ and gallic acid $(163.30 \mu \mathrm{g} / \mathrm{mL})$. The LC-MS results revealed that $P$. amarus extract consisted of 18 compounds identified via positive ionization mode

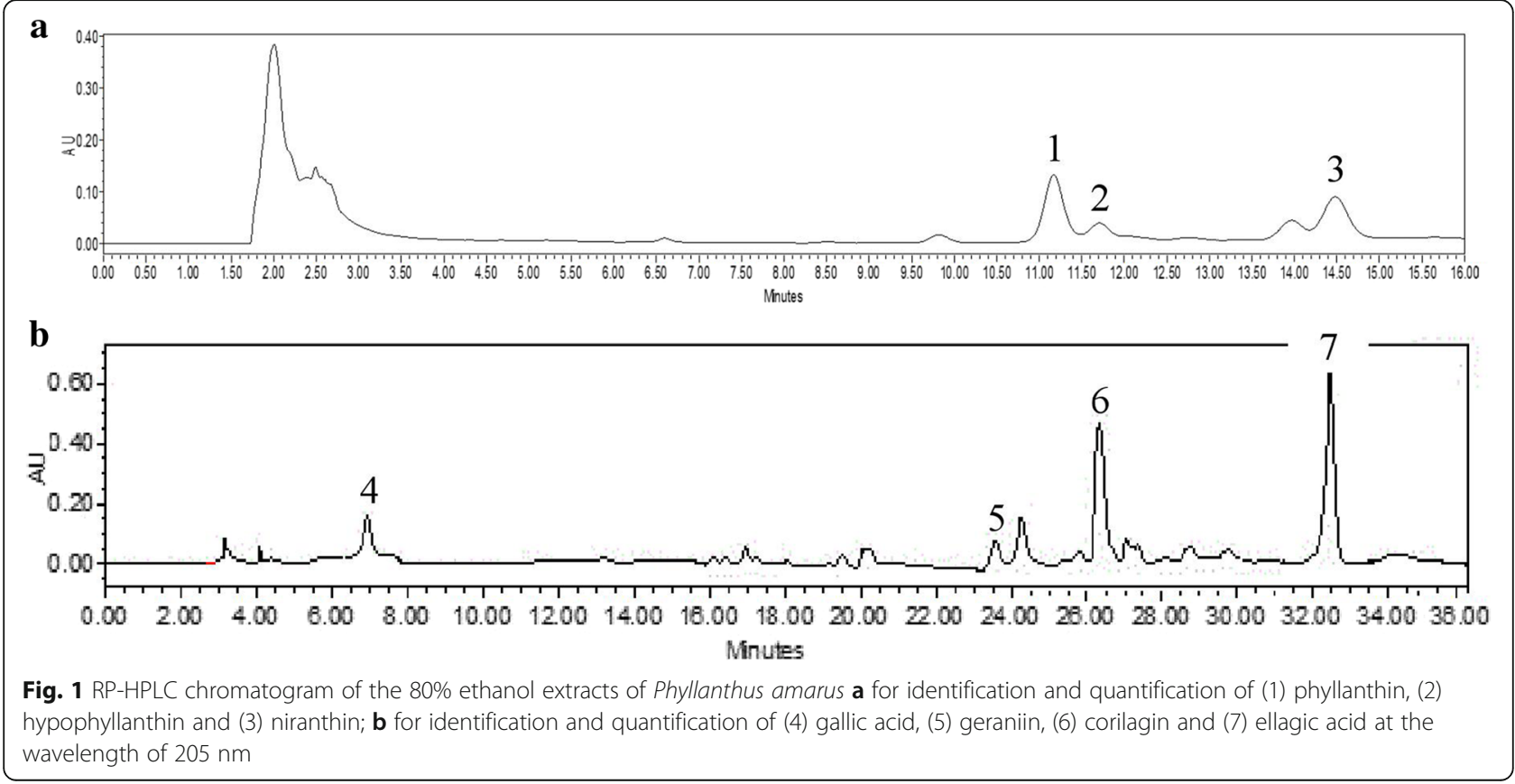


while five compounds identified via negative ionization mode (Table 1).

\section{Effects of $P$. amarus on cell viability}

U937 macrophages were incubated with the $80 \%$ ethanolic extract of $P$. amarus ranging from 0 to $60 \mu \mathrm{g} / \mathrm{mL}$ and cell viability was determined by alamar blue assay after $24 \mathrm{~h}$. The results demonstrated that from 0 to $60 \mu \mathrm{g} / \mathrm{mL}$ of $P$. amarus extract, there was no cytotoxic effect on U937 macrophages (cell viability greater than 90\%). These results confirmed that the effects of P. amarus on U937 macrophages in this study were not due to cytotoxicity.

\section{Effects of $P$. amarus on pro-inflammatory cytokines production and gene expression}

To investigate the anti-inflammatory effects of $P$. amarus extract on LPS-stimulated macrophages, firstly the concentrations of TNF- $\alpha$ and IL- $1 \beta$ in the culture supernatants of U937 macrophages were determined by ELISA kit. The results demonstrated that, the pro- inflammatory cytokines (TNF- $\alpha$ and IL-1 $\beta$ ) production was significantly upregulated in LPS induced U937 macrophages while the cells pretreated with $P$. amarus for $2 \mathrm{~h}$ prior to LPS stimulation showed suppressive effect on TNF- $\alpha$ and IL- $1 \beta$ production with $\mathrm{IC}_{50}$ values of 16.12 and $7.13 \mu \mathrm{g} / \mathrm{mL}$, respectively (Fig. $2 \mathrm{a}$ and b). In addition, the suppressive effect also was observed for sample treated with an standard anti-inflammatory agent, dexamethasone which exhibited inhibitory activity on TNF- $\alpha$ and IL-1 $\beta$ with $\mathrm{IC}_{50}$ values of $0.18 \mu \mathrm{g} / \mathrm{mL}$ and $0.002 \mu \mathrm{g} / \mathrm{mL}$, respectively. Next, we determined the effects of $P$. amarus on pro-inflammatory cytokines expression at pre-translational level by using quantitative Real-Time RT-PCR (qRT-PCR). As shown in Additional file 1: Figure S1, the mRNA expression of TNF- $\alpha$ and IL- $1 \beta$ were significantly $(P<0.001)$ upregulated in U937 macrophages $24 \mathrm{~h}$ following LPS stimulation. However, the cells pretreated with $P$. amarus (60, 30 and $15 \mu \mathrm{g} / \mathrm{mL})$ for $2 \mathrm{~h}$ showed a significant inhibition in LPS induced TNF- $\alpha$ (27, 32, and 35 fold, respectively) and IL- $1 \beta$ (12, 32, and 35 fold, respectively) (Fig. 2c and d). These gene expression levels also were comparable with $4 \mu \mathrm{g} / \mathrm{mL}$ dose of dexamethasone pretreated cells prior to LPS induction. Dexamethasone pretreated cells also showed an inhibition of TNF- $\alpha$ and IL-1 $\beta$ expression ( 8 and 2 fold respectively) (Fig. $2 \mathrm{c}$ and d). The consistent inhibition of cytokine expression at protein and mRNA levels suggests that $P$. amarus may exert their anti-inflammatory effects by controlling gene transcription.

Table 1 Tentative compounds detected in 80\% ethanol extract of Phyllanthus amarus by LCMS analysis

\begin{tabular}{|c|c|c|c|c|}
\hline Peak & Retention time (RT) & Molecular ion peak & $\mathrm{MS}^{2}$ fragment ions & Tentative compounds identified \\
\hline 1 & 1.7 & $131(\mathrm{M}-\mathrm{H})^{-}$ & $909,688,244,134$ & D-glutamine \\
\hline 2 & 2.0 & $195(M-H)^{-}$ & $909,678,404,204$ & Gluconic acid \\
\hline 3 & 2.1 & $228(\mathrm{M}-\mathrm{H})^{-}$ & $897,709,405,238,129$ & Naringenin \\
\hline 4 & 2.1 & $191(M-H)^{-}$ & $935,596,381,191$ & Quinic acid \\
\hline 5 & 2.6 & $133(\mathrm{M}-\mathrm{H})^{-}$ & $913,677,412,230,134$ & D-(+)-Malic acid \\
\hline 6 & 2.9 & $321(\mathrm{M}-\mathrm{H})^{-}$ & $711,412,248,183$ & Dinitramin \\
\hline 7 & 3.1 & $128(\mathrm{M}-\mathrm{H})^{-}$ & 122 & 4-oxoproline \\
\hline 8 & 4.2 & $387(\mathrm{M}-\mathrm{H})^{-}$ & $514,387,207$ & galloyl glucopyroxidase \\
\hline 9 & 6.5 & $169(\mathrm{M}-\mathrm{H})^{-}$ & 169 & Gallic acid \\
\hline 10 & 7.0 & $343(\mathrm{M}-\mathrm{H})^{-}$ & 169 & trio-O-methylellagic acid \\
\hline 11 & 7.9 & $633(\mathrm{M}-\mathrm{H})^{-}$ & $633,463,301$ & corilagin \\
\hline 12 & 8.0 & $331(\mathrm{M}-\mathrm{H})^{-}$ & 169 & tuberonic acid hexoside \\
\hline 13 & 8.5 & $951(\mathrm{M}-\mathrm{H})^{-}$ & $933,765,613,463,301$ & geraniin \\
\hline 14 & 8.9 & $965(\mathrm{M}-\mathrm{H})^{-}$ & $933,765,609,300$ & Rutin \\
\hline 15 & 9.2 & $197(\mathrm{M}-\mathrm{H})^{-}$ & 125 & Syringic acid \\
\hline 16 & 9.2 & $463(\mathrm{M}-\mathrm{H})^{-}$ & $463,300,169$ & Quercetine 3-D-glucoside \\
\hline 17 & 9.5 & $206(M-H)^{-}$ & $873,704,558,226,147$ & $\mathrm{~N}$-acetyl-D-phenylalanine \\
\hline 18 & 9.7 & $247(\mathrm{M}-\mathrm{H})^{-}$ & 247 & 7-Deshydroxypyrogallin4- carboxylic acid \\
\hline 19 & 1.6 & $133(\mathrm{M}-\mathrm{H})^{+}$ & $663,383,132$ & Maleamate \\
\hline 20 & 1.8 & $222(\mathrm{M}-\mathrm{H})^{+}$ & 222 & Metaxalone \\
\hline 21 & 1.9 & $184(\mathrm{M}-\mathrm{H})^{+}$ & 184 & 4-pyridoxic acid \\
\hline 22 & 3.6 & $166(\mathrm{M}-\mathrm{H})^{+}$ & 120 & Stachydrine \\
\hline 23 & 13.9 & $419(\mathrm{M}-\mathrm{H})^{+}$ & 419,149 & Phyllanthin \\
\hline
\end{tabular}




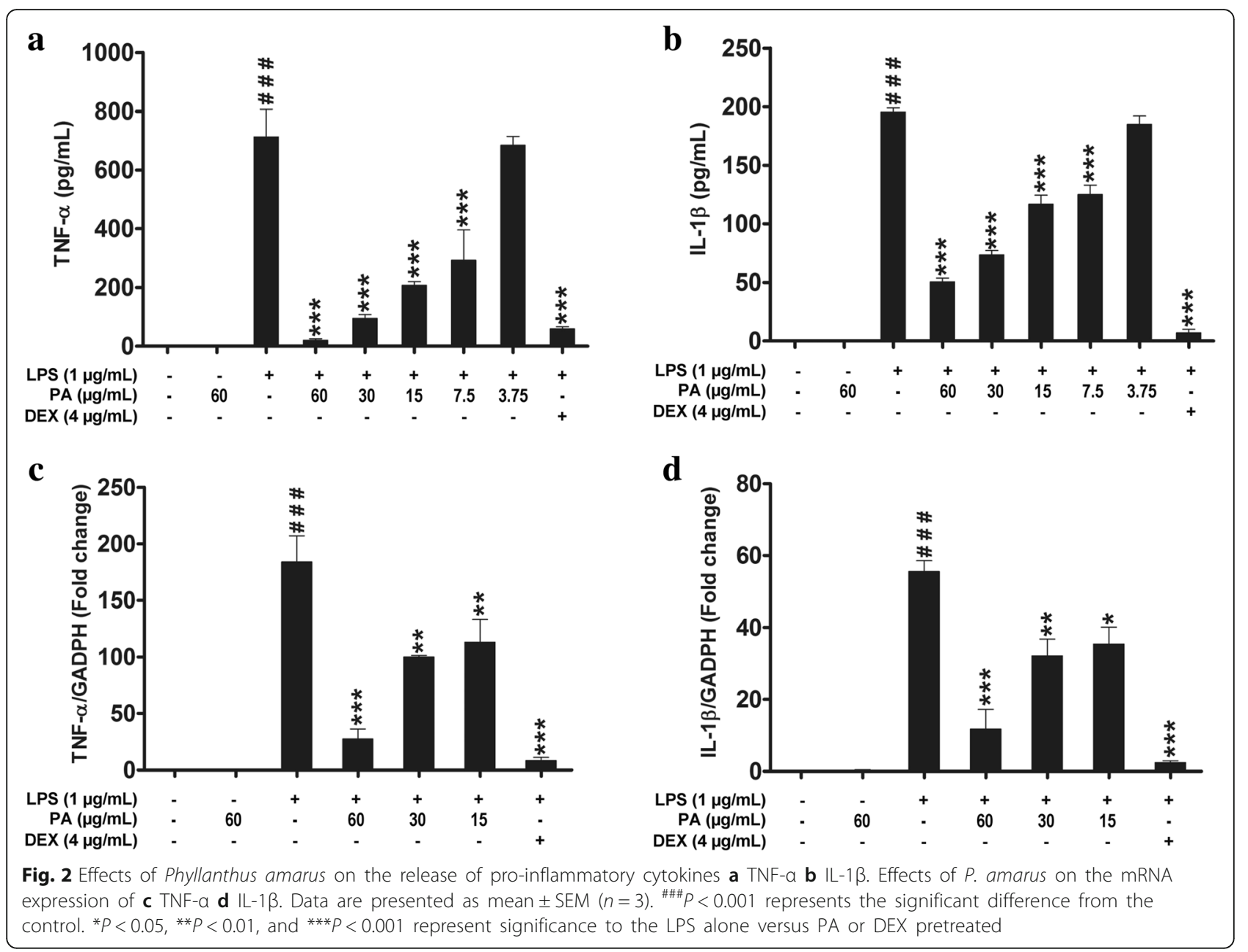

Effects of $P$. amarus on $\mathrm{PGE}_{2}$ production and COX-2 expression

To examine the effect of $P$. amarus on $\mathrm{PGE}_{2}$ release, production of $\mathrm{PGE}_{2}$ in culture supernatant was measured. $\mathrm{PGE}_{2}$ production was measured in U937 macrophages induced with LPS for $24 \mathrm{~h}$ in the presence and absence of $P$. amarus. As shown in Fig. 3a, LPS $(1 \mu \mathrm{g} / \mathrm{mL})$ induced U937 macrophages produced significant amount of $\mathrm{PGE}_{2}$ $(1128.67 \pm 200.07 \mathrm{pg} / \mathrm{mL})$ compared to control (31.33 \pm $11.31 \mathrm{pg} / \mathrm{mL})$. However, the production of $\mathrm{PGE}_{2}$ was significantly attenuated by $P$. amarus pretreatment at 60 , 30 and $15 \mu \mathrm{g} / \mathrm{mL}$ in a dose- dependent manner. In order to examine the mechanisms by which $P$. amarus inhibited LPS- induced $\mathrm{PGE}_{2}$ release, the expression of COX-2 at protein and gene level was measured in U937 macrophages induced with LPS. As shown in Fig. 3b, Western blot analysis showed that $24 \mathrm{~h}$ LPS stimulation significantly $(P<0.001)$ upregulated the COX-2 protein expression while $2 \mathrm{~h} P$. amarus $(60,30$ and $15 \mu \mathrm{g} / \mathrm{mL}$ ) pretreatment significantly attenuated the expression in a dose-dependent manner. In addition, we have investigated the effects of $P$. amarus on gene expression to determine whether $P$. amarus inhibited the LPS induced COX-2 mRNA level in U937 macrophages. As shown in Fig. 3c, the significantly $(P<0.001)$ increased COX-2 mRNA expression (282 fold) in LPS stimulated cells were significantly attenuated in $P$. amarus $(60$ and $30 \mu \mathrm{g} / \mathrm{mL})$ pretreated cells (137 and 259 fold, respectively) as compared to control.

\section{Effects of $P$. amarus on NF-KB signaling pathways}

To determine the role of $\mathrm{IKK} / \mathrm{I} \kappa \mathrm{B} / \mathrm{NF}-\mathrm{kB}$ signaling pathway in $P$. amarus mediated inhibition of LPS-induced inflammatory response, we studied the activation of $\mathrm{p}-\mathrm{NF}-\kappa \mathrm{B}(\mathrm{p} 65), \mathrm{NF}-\mathrm{kB}(\mathrm{p} 65), \mathrm{p}-\mathrm{I} \kappa \mathrm{B} \alpha$, $\mathrm{I} \kappa \mathrm{B} \alpha, \mathrm{p}-\mathrm{IKK} \alpha \alpha / \beta$, and $\mathrm{IKK} \alpha / \beta$ in LPS-induced human macrophages by Western blot. Our results demonstrated that, $P$. amarus altered the NF- $\mathrm{B}$ signaling mechanisms by suppressing the phosphorylation of $\mathrm{IKK} \alpha / \beta$ and $\mathrm{I}_{\kappa} \mathrm{B} \alpha$ in a dose-dependent manner, which were significantly $(P<0.001)$ upregulated by $30 \mathrm{~min}$ LPS treatment. In addition, the $2 \mathrm{~h} P$. amarus pretreatment significantly blocked the degradation of 

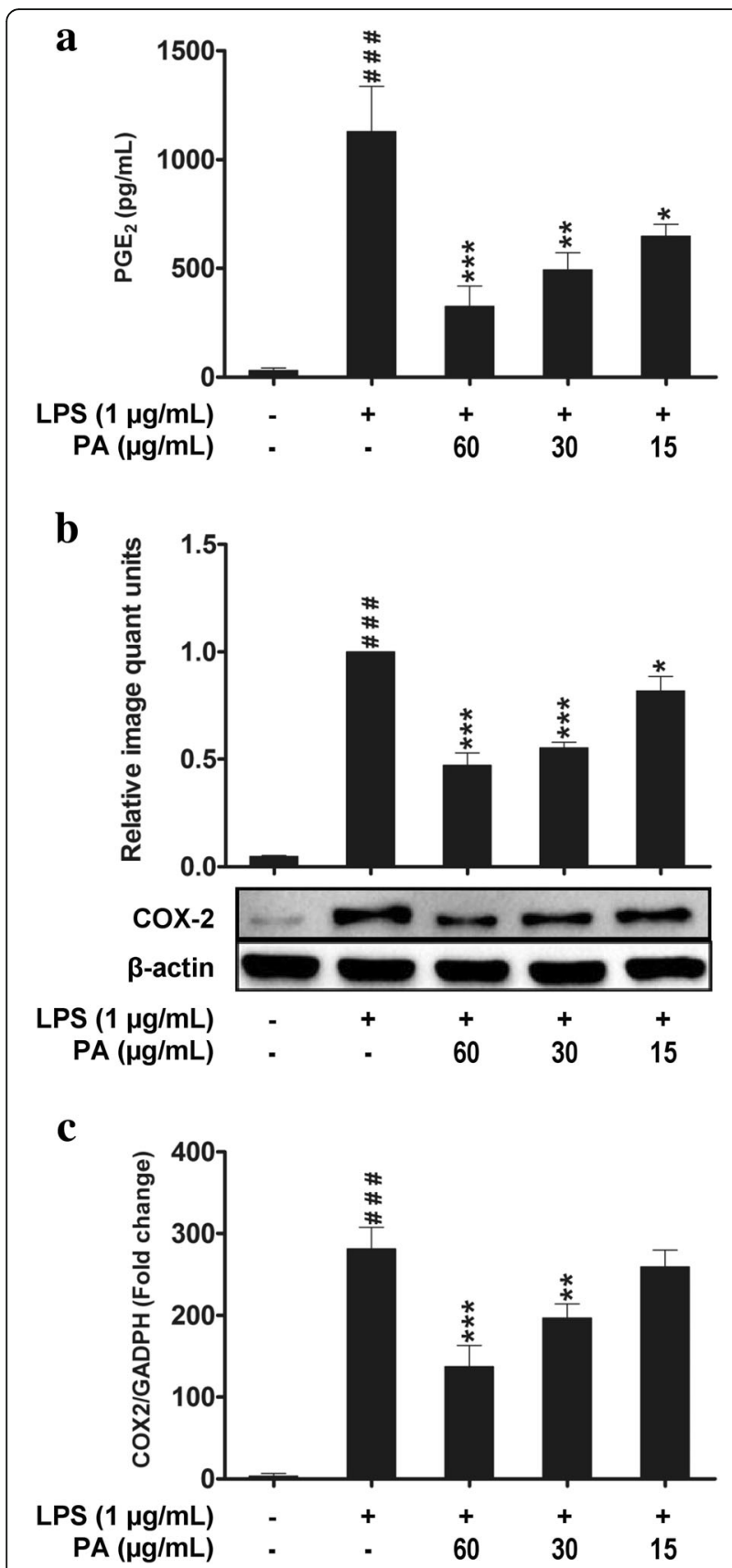

Fig. 3 Effects of Phyllanthus amarus on the release of $P G E_{2}$ production (a). Effects of P. amarus on COX-2 protein expression (b) and mRNA expression (c). Data are presented as mean \pm SEM with $(n=3) .{ }^{\# \# \#} P<0.001$ represents the significant difference from the control. ${ }^{*} P<0.05$, ${ }^{* *} P<0.01$, and ${ }^{* * *} P<0.001$ represent significance to the LPS alone versus PA

LPS induced $I \kappa B \alpha$ in a concentration-dependent manner (Additional file 2: Figure S2). Furthermore, the $2 \mathrm{~h}$ pretreatment with $P$. amarus also significantly attenuated the LPS-induced phospho-p65 without altering the total level of p65 in human U937 macrophages (Fig. 4).
Effects of $P$. amarus on MAPKs and PI3K-Akt activation Studies have demonstrated that the activation of Akt and MAPKs (JNK1/2, ERK1/2, and p38) signaling molecules is important to initiate and mediate the NF- $\mathrm{BB}$ signal transduction pathway. Hence,we investigated the effect of $P$. amarus on phosphorylation of Akt by Western blot analysis. As depicted in Fig. 5, the 30 min LPS induction significantly upregulated Akt phosphorylation while $2 \mathrm{~h} P$. amarus pretreatment dose-dependently suppressed the phosphorylation. Furthermore, the effect of PA on phosphorylation activity of three important MAPKs signaling molecules (JNK1/2, ERK1/2, and p38) was also investigated. The LPS induction at $30 \mathrm{~min}$ significantly $(P<0.001)$ stimulated the JNK1/2, ERK1/2, and p38 phosphorylation levels in macrophages but the cells pretreated with $P$. amarus $(60,30$ and $15 \mu \mathrm{g} / \mathrm{ml})$ for $2 \mathrm{~h}$ significantly suppressed the phosphorylation of JNK1/2, ERK1/2, and p38 protein kinases in a dose-dependent manner without interfering the total level of JNK1/2, ERK1/2, and p38 protein kinases (Fig. 5).

In order to further validate that the suppression of inflammatory mediators by $P$. amarus linked to the NF- $\mathrm{B}, \mathrm{MAPKs}$, and Akt signaling pathway down regulation, we examined the effect of specific NF- $\kappa B$, MAPKs, and Akt inhibitors on TNF- $\alpha$ production and COX-2 protein expression. The $2 \mathrm{~h}$ pretreatment of LPS-induced macrophages with BAY 11-7082 (an NF- $\mathrm{kB}$ inhibitor), LY294002 (an Akt inhibitor), SB202190 (a p38 inhibitor), U0126 (an ERK inhibitor) and SP600125 (a JNK inhibitor) showed significant inhibitory effect on TNF- $\alpha$ production and COX-2 expression (Fig. 6). Taken together, our results suggest that $P$. amarus reduced COX-2 expression and TNF- $\alpha$ production by down regulating LPS-activated NF-kB, ERK, JNK, p38MAPKs and Akt signaling pathways.

\section{Effects of $P$. amarus on MyD88 and TLR4 signaling molecules}

To further confirm the anti- inflammatory activity of $P$. amarus, the expression of MyD88 and TLR4 were investigated in LPS-induced U937 macrophages. As shown in Fig. $7,1 \mathrm{~h}$ LPS induction significantly $(P<0.001)$ upregulated the expression of MyD88 and TLR4 compared to control cells. However, the cells pretreated with $P$. amarus for $2 \mathrm{~h}$ dose- dependently diminished the upregulation of MyD88 and TLR4 protein expression. It was noted that, at the dose of $60 \mu \mathrm{g} / \mathrm{mL}$, the suppression of $P$. amarus was found highly significant $(P<0.001)$ for the both upstream signaling molecules.

\section{Discussion}

$P$. amarus is a promising herbal resource with therapeutic potential against various diseases due to the presence of numerous active and secondary metabolites [22]. 


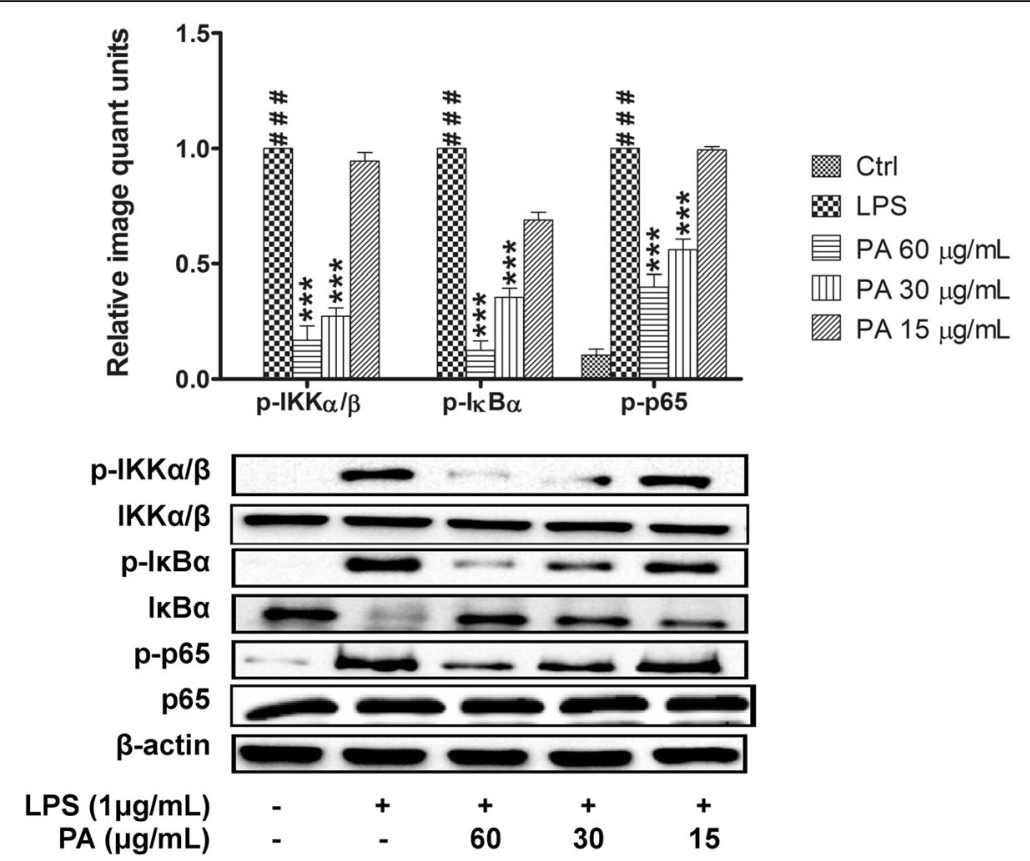

Fig. 4 Effects of Phyllanthus amarus on phosphorylation of IKKa/ $\beta$, IKBa and NF-KB (p65). Data are presented as mean \pm SEM with $(n=3)$. \#\#\# $P<0.001$ represents the significant difference from the control. ${ }^{*} P<0.05$, ${ }^{*} P<0.01$, and ${ }^{* * *} P<0.001$ represent significance to the LPS alone versus PA

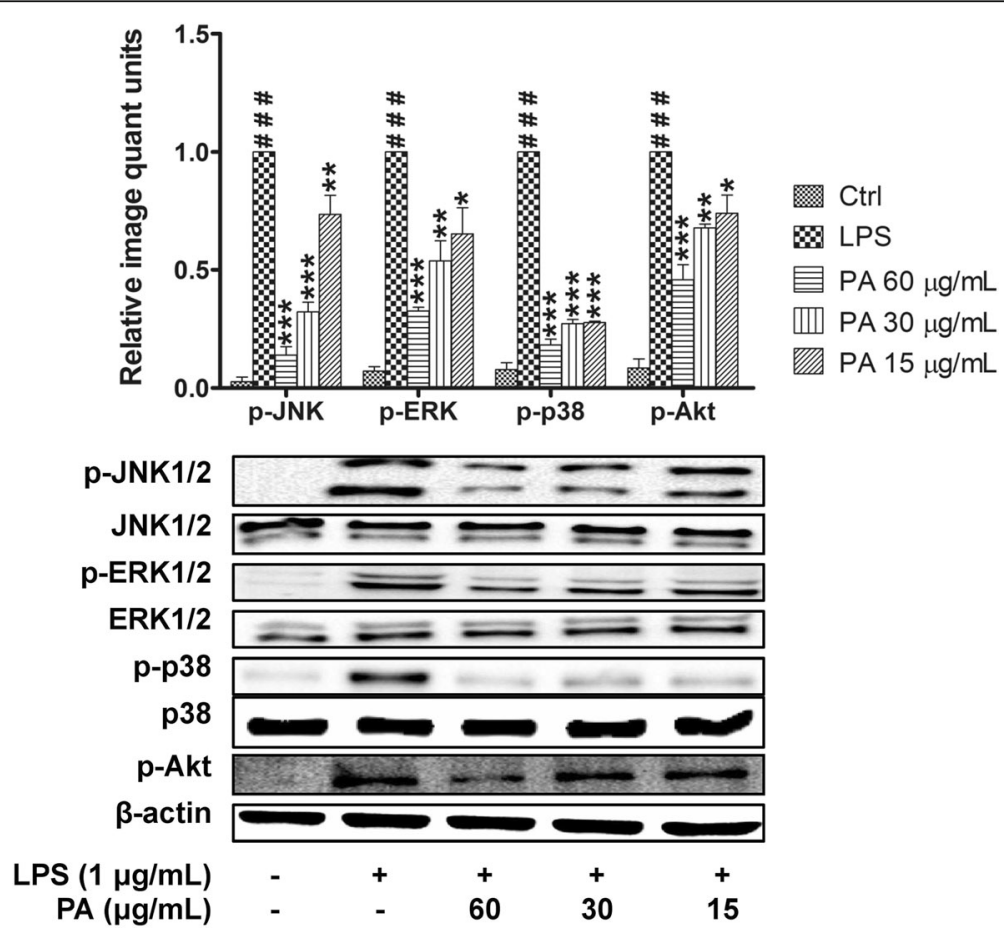

Fig. 5 Effects of Phyllanthus amarus on p-JNK, p-ERK, p-p38 and p-Akt expression. Data are presented as mean \pm SEM with $(n=3)$. \#\#\# $P<0.001$ represents the significant difference from the control. ${ }^{*} P<0.05$, ${ }^{*} P<0.01$, and ${ }^{* *} P<0.001$ represent significance to the LPS alone versus PA 

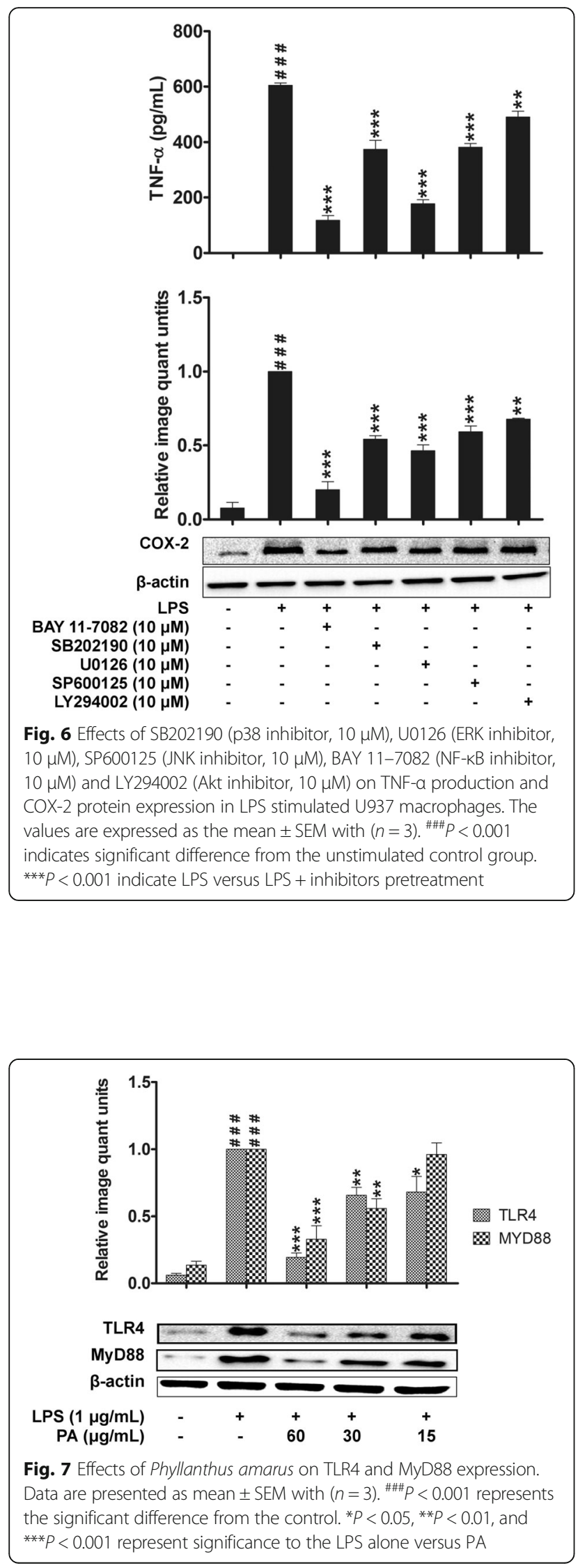

Although $P$. amarus extracts have been previously shown to possess immunosuppressive activity on immune cells but the mechanism underlying the anti-inflammatory activity of the plant remain unknown [27, 32-34]. Therefore, in the present study we investigated the in vitro effects of $P$. amarus by using LPS-activated U937 human macrophage, which mimics the inflammatory model [1]. Macrophages can be activated by LPS to produce pro-inflammatory molecules such as IL-6, TNF- $\alpha$, IL- $1 \beta$, $\mathrm{PGE}_{2}$ and $\mathrm{NO}$ by triggering intracellular signaling pathways including NF- $\mathrm{kB}$ and MAPKs $[1,2,35]$.

COX is known as an enzyme which aid in the process converting the arachidonic acid to prostaglandins and it exists as COX-1 and COX-2 isomers. COX-1 is responsible for the homeostatic function of $\mathrm{PGE}_{2}$ while COX-2 triggers the excess release of $\mathrm{PGE}_{2}$ at the region of inflammation which is known to play critical role during pathogenesis of chronic diseases [31, 36, 37]. Besides, it is also reported that overexpression of COX-2 leads to the upregulation of several angiogenic mediators [38]. Therefore, potent inhibitory effects of anti-inflammatory drugs on COX-2 expression have been revealed by several researches to be valuable in preventing and curing these disorders [39]. In current study, we found that $P$. amarus extract suppressed the $\mathrm{PGE}_{2}$ production in LPS stimulated U937 macrophages by down regulating the COX-2 protein and gene expression. These finding suggest that the suppression of $\mathrm{PGE}_{2}$ release by $P$. amarus extract might be due to the inhibition of COX-2 elevation upon the LPS induction of macrophages. Furthermore, Kiemer et al. also reported the inhibitory effect of $P$. amarus extract on $\mathrm{PGE}_{2}$ production in rat Kupffer cells and RAW264.7 macrophages, whick were in consistent with our present finding. Like COX-2, iNOS is also one of the enzyme that is involved in the production of excess $\mathrm{NO}$ during chronic inflammatory disorders to alleviate the pathogenesis of disease state [38]. It is to be noted that from our experiment NO could not be detected at measurable quantity in the LPS induced U937 macrophages which is in agreement with the previous report [40]. The probable reason for this occurrence may linked to the statement that, U937 cells lack of BH4 (tetrahydrobiopterin) which is the crucial cofactor for NO production $[19,41]$. TNF- $\alpha$ and IL-1 $\beta$ are known as a key pro-inflammatory cytokines that are secreted during the development of chronic inflammatory diseases [42]. In this study we found that the extract of $P$. amarus and positive control, dexamethasone showed a significant inhibition of pro-inflammatory cytokines in a concentration-dependent manner in LPS-stimulated human macrophages. The outcome was found in line with the previous study where the inhibitory effect of $P$. amarus on pro-inflammatory cytokines such as TNF- $\alpha$, IL- $1 \beta$ and IFN- $\gamma$ in LPS induced immune cells has also been observed [32]. 
NF- $\mathrm{kB}$ signaling plays a major role in macrophages to regulate the cell survival genes and induces transcription and translation of other mediators that are involved in inflammatory response [43]. Thus, the inhibition of these signaling pathways may highlight the potential of $P$. amarus as a suppressor of inflammatory cytokines. Consistent with previous report, $P$. amarus ethanolic extract inhibited the production of LPS-induced TNF- $\alpha$ and IL- $1 \beta$ that are known to regulate by NF- $\mathrm{KB}$ signaling pathway. Interestingly, our present findings revealed that $P$. amarus extracts dose -dependently diminished the phosphorylation of $I K K \alpha / \beta$ and IKB $\alpha$ in response to LPS. Furthermore, LPS-induced IкB $\alpha$ degradation in U937 cells also inhibited by $P$. amarus in a dose dependent manner. These findings indicate that the downregulation of LPS-induced inflammatory cytokines production by $P$. amarus results from the blockade of $\mathrm{IKK} / \mathrm{I} \kappa \mathrm{B} / \mathrm{NF}-\mathrm{kB}$ signaling pathway. A study has reported that $P$. amarus inhibited the DNA binding activity of NF-kB binding factors and also iNOS and COX-2 expression in LPS-induced murine macrophages [32]. This is in agreement with our findings which showed that $P$. amarus was able to downregulate the NF- $\mathrm{kB}$ activation by suppressing the release of pro- inflammatory mediators.

Apart from NF-kB, LPS-induced macrophages also activate MAPKs signaling pathway, which regulate the expression of inflammatory mediators by controlling NF- $\mathrm{kB}$ activity [44]. Our study demonstrated that pretreatment of cell with $P$. amarus inhibited the early activation of cell by LPS in a dose-dependent manner. Thus, our study strongly indicates that the MAPKs (JNK, ERK, and p38) were involved in inhibitory activity of $P$. amarus on the expression of pro-inflammatory mediators. Apart from NF- $\mathrm{KB}$ and MAPKs, phosphatidylinositol 3-kinase/Akt (PI3K-Akt) is another signaling pathway which is activated in LPS induced macrophages to control the expression of inflammatory markers by activating the NF- $\mathrm{kB}$ signal transduction pathway [45]. Hence, blocking the phosphorylation activity of Akt in response to LPS induction is known to be an important target to control inflammatory disorders. Supportingly, our study revealed that, $P$. amarus pretreatment significantly attenuated the LPS induced Akt phosphorylation in LPS induced human macrophages. Furthermore, in this study we proved that the suppression of TNF- $\alpha$ production and COX-2 protein expression by $P$. amarus were due to the blockage of NF- $\mathrm{kB}$, MAPKs, and Akt pathways through the use of NF- $\mathrm{kB}, \mathrm{MAPKs}$, and Akt inhibitors.

TLR4 is known to specifically bind with LPS and trigger inflammatory response by activating NF- $\mathrm{kB}$, MAPKs, and PI3K-Akt signaling pathways which lead to the production of inflammatory mediators $[1,46,47]$. The activated TLR4 sequentially transmit the inflammatory signals through the adaptor protein, Myd88 [48].
This suggests that, TLR4 and MyD88 act as a specific molecular target to inititate inflammatory responses [47, 49]. Our investigation demonstrates that $P$. amarus significantly inhibited LPS-induced TLR4 and MyD88 expression in U937 macrophages. These findings propose that TLR4 and MyD88 participated in the inhibitory action of $P$. amarus on the LPS-induced production of $\mathrm{PGE}_{2}$ and pro-inflammatory cytokines.

\section{Conclusions}

In conclusion, the present study demonstrated that $P$. amarus potently suppressed the inflammatory responses in LPS-induced U937 macrophages via inhibition of MyD88-dependent signaling pathway, which may be linked to the inhibitory effects exerted by $P$. amarus on pro-inflammatory mediators. Therefore, the ethanol extract of $P$. amarus have promising anti-inflammatory activity which acts through the suppression of NF- $k B$, MAPKs, and PI3K-Akt signaling pathways and may have beneficial therapeutic applications for treating inflammatory disorders.

\section{Additional files}

Additional file 1: Figure S1. The mRNA expression of TNF- $\alpha$ and IL-1 $\beta$ at various time points. (TIF $3977 \mathrm{~kb}$ )

Additional file 2: Figure S2. Effects of Phyllanthus amarus on degradation of IkBa. (TIF $97 \mathrm{~kb}$ )

\section{Abbreviation}

ATCC: American type culture collection; COX2: Cyclooxygenase 2; ELISA: Enzyme-linked immunosorbant assay; ERK: Extracellular signalregulated kinase; FBS: Fetal bovine serum; HPLC: High performance liquid chromatography; IL-1 $\beta$ : Interleukin 1 beta; iNOS: Inducible nitric oxide synthase; IkB: I-kappa B kinase; JNK: c-Jun N-terminal kinase; LPS: Lipopolysaccahride; MAPK: Mitogen activated protein kinase; MyD88: Myeloid differentiation primary response gene 88; NF-KB: Nuclear factor-kappa B; NO: Nitric oxide; NSAID: Non-steroidal anti-inflammatory drug; PA: Phyllanthus amarus; PGE 2 : Prostaglandin E2; PMA: Phorbol 12-myristate 13-acetate; RPMI: Roswell park memorial institute; TLR4: Toll like receptor 4; TNF-a: Tumor necrosis factor-alpha

\section{Acknowledgements}

This work was supported by the Ministry of Agriculture and Agro-based Industry, Malaysia, under the NKEA Research Grant Scheme (NRGS) (Grant no. NH1014D020)

\section{Funding}

This study was funded by the Ministry of Agriculture Malaysia under the NKEA Research Grant Scheme (NRGS) (no. NH0811D003).

\section{Availability of data and materials}

The data analyzed and materials used in this study are available from the corresponding author on reasonable request.

\section{Authors' contributions}

HK carried out the experiments, analyzed and interpreted the data, and drafted the manuscript. IJ and EK designed the study and participated in analysis and interpretation of data. IJ coordinated the study, revised the manuscript and approved the final version to be submitted for publication. $\mathrm{MAH}$ helped in the analysis and interpretation of data. All authors read and approved the final manuscript. 


\section{Ethics approval and consent to participate}

Not applicable.

\section{Consent for publication \\ Not applicable.}

\section{Competing interests}

The authors declare that they have no competing interest.

\section{Publisher's Note}

Springer Nature remains neutral with regard to jurisdictional claims in published maps and institutional affiliations.

\section{Received: 16 February 2018 Accepted: 13 July 2018} Published online: 25 July 2018

\section{References}

1. Haque MA, Jantan I, Harikrishnan H. Zerumbone suppresses the activation of inflammatory mediators in LPS-stimulated U937 macrophages through MyD88-dependent NF-KB/MAPK/PI3K-Akt signaling pathways. Int Immunopharmacol. 2018:55:312-22

2. Haque MA, Jantan I, Harikrishnan H, Abdul Wahab SM. Magnoflorine enhances LPS-activated pro-inflammatory responses via MyD88-dependent pathways in U937 macrophages. Planta Med. 2018; https://doi.org/10.1055/ a-0637-9936.

3. Chen GY, Nunez G. Sterile inflammation: sensing and reacting to damage. Nat Rev Immunol. 2010;10(12):826-37.

4. Shacter E, Weitzman SA. Chronic inflammation and cancer. Oncology. 2002; 16(2):217-226, 229. discussion 230-212

5. Killeen MJ, Linder M, Pontoniere P, Crea R. NF-kappabeta signaling and chronic inflammatory diseases: exploring the potential of natural products to drive new therapeutic opportunities. Drug Discov Today. 2014;19(4):373-8.

6. Aggarwal BB. Nuclear factor-kappaB: the enemy within. Cancer Cell. 2004; 6(3):203-8.

7. Karin M, Ben-Neriah Y. Phosphorylation meets ubiquitination: the control of NF-[kappa]B activity. Annu Rev Immunol. 2000:18:621-63.

8. Pasparakis M. Regulation of tissue homeostasis by NF-kappaB signalling: implications for inflammatory diseases. Nat Rev Immunol. 2009;9(11):778-88.

9. Guha M, Mackman N. LPS induction of gene expression in human monocytes. Cell Signal. 2001;13(2):85-94.

10. Lawrence T, Fong $\mathrm{C}$. The resolution of inflammation: anti-inflammatory roles for NF-kappaB. Int J Biochem Cell Biol. 2010;42(4):519-23.

11. Thalhamer T, McGrath MA, Harnett MM. MAPKs and their relevance to arthritis and inflammation. Rheumatol. 2008;47(4):409-14.

12. Vanden Berghe W, Plaisance S, Boone E, De Bosscher K, Schmitz ML, Fiers W, Haegeman G. p38 and extracellular signal-regulated kinase mitogenactivated protein kinase pathways are required for nuclear factor-kappaB p65 transactivation mediated by tumor necrosis factor. J Biol Chem. 1998; 273(6):3285-90.

13. Hwang PA, Chien SY, Chan YL, Lu MK, Wu CH, Kong ZL, Wu CJ. Inhibition of lipopolysaccharide (LPS)-induced inflammatory responses by Sargassum hemiphyllum sulfated polysaccharide extract in RAW 264.7 macrophage cells. J Agric Food Chem. 2011;59(5):2062-8.

14. Paccani SR, Boncristiano M, Ulivieri C, D'Elios MM, Del Prete G, Baldari CT. Nonsteroidal anti-inflammatory drugs suppress T-cell activation by inhibiting p38 MAPK induction. J Biol Chem. 2002;277(2):1509-13.

15. Patil W, Bhangale SC, Patil VR. Studies on immunomodulatory activity of Ficus carica. Int J Pharm Pharm Sci. 2010:2(4):97-9.

16. Jayathirtha MG, Mishra SH. Preliminary immunomodulatory activities of methanol extracts of Eclipta alba and Centella asiatica. Phytomedicine. 2004; 11(4):361-5.

17. Patel JR, Tripathi P, Sharma V, Chauhan NS, Dixit VK. Phyllanthus amarus: ethnomedicinal uses, phytochemistry and pharmacology: a review. J Ethnopharmacol. 2011;138(2):286-313.

18. Calixto JB, Santos AR, Cechinel Filho V, Yunes RA. A review of the plants of the genus Phyllanthus: their chemistry, pharmacology, and therapeutic potential. Med Res Rev. 1998;18(4):225-58

19. Harikrishnan H, Jantan I, Haque MA, Kumolosasi E. Anti-inflammatory effects of hypophyllanthin and niranthin through downregulation of NF-KB/MAPKs/ PI3K-Akt signaling pathways. Inflammation. 2018;41(3):984-95.
20. Foo LY. Amariin, a di-dehydrohexahydroxydiphenoyl hydrolysable tannin from Phyllanthus amarus. Phytochemistry. 1993;33(2):487-91.

21. Sharma A, Singh RT, Handa SS. Estimation of phyllanthin and hypophyllanthin by high performance liquid chromatography in Phyllanthus amarus. Phytochem Anal. 1993;4(5):226-9.

22. Houghton PJ, Woldemariam TZ, O'Shea S, Thyagarajan S. Two securinegatype alkaloids from Phyllanthus amarus. Phytochemistry. 1996;43(3):715-7.

23. Moronkola DO, Ogunwande IA, Oyewole IO, Başer KHC, Ozek T, Ozek G. Studies on the volatile oils of Momordica charantia L. (Cucurbitaceae) and Phyllanthus amarus Sch. Et Thonn (Euphorbiaceae). J Essent Oil Res. 2009;21(5):393-9.

24. Mahat $\mathrm{M}$, Patil B. Evaluation of antiinflammatory activity of methanol extract of Phyllanthus amarus in experimental animal models. Indian J Pharm Sci. 2007;69(1):33.

25. Kassuya CA, Silvestre A, Menezes-de-Lima O, Marotta DM, Rehder VLG, Calixto JB. Antiinflammatory and antiallodynic actions of the lignan niranthin isolated from Phyllanthus amarus: evidence for interaction with platelet activating factor receptor. Eur J Pharmacol. 2006;546(1):182-8.

26. Yuandani IM, Jantan I, Mohamad HF, Husain K, Abdul Razak AF. Inhibitory effects of standardized extracts of Phyllanthus amarus and Phyllanthus urinaria and their marker compounds on phagocytic activity of human neutrophils. Evid Based Complement Alternat Med. 2013;2013:603634.

27. Jantan I, llangkovan M, Mohamad HF. Correlation between the major components of Phyllanthus amarus and Phyllanthus urinaria and their inhibitory effects on phagocytic activity of human neutrophils. BMC Complement Altern Med. 2014;14(1):429.

28. Ilangkovan M, Jantan I, Mesaik MA, Bukhari SNA. Immunosuppressive effects of the standardized extract of Phyllanthus amarus on cellular immune responses in Wistar-Kyoto rats. Drug Des Dev Ther. 2015;9:4917.

29. Ilangkovan M, Jantan I, Mesaik MA, Bukhari SNA. Inhibitory effects of the standardized extract of Phyllanthus amarus on cellular and humoral immune responses in Balb/C mice. Phytother Res. 2016;30(8):1330-8.

30. Sock-Jin L, Kumolosasi E, Azmi N, Bukhari SNA, Jasamai M, Fauzi NM. Effects of synthetic chalcone derivatives on oxidised palmitoyl arachidonoyl phosphorylcholine-induced proinflammatory chemokines production. RSC Adv. 2015;5(84):68773-80.

31. Aluwi MFFM, Rullah $\mathrm{K}$, Haque MA, Yamin BM, Ahmad W, Amjad MW, Leong SW, Fahmizar NA, Jalil J, Abas F. Suppression of PGE2 production via disruption of MAPK phosphorylation by unsymmetrical dicarbonyl curcumin derivatives. Med Chem Res. 2017;26(12):3323-35.

32. Kiemer AK, Hartung T, Huber C, Vollmar AM. Phyllanthus amarus has antiinflammatory potential by inhibition of iNOS, COX-2, and cytokines via the NF-kB pathway. J Hepatol. 2003;38(3):289-97.

33. Ilangkovan M, Jantan I, Mohamad HF, Husain K, Abdul Razak AF. Inhibitory effects of standardized extracts of Phyllanthus amarus and Phyllanthus urinaria and their marker compounds on phagocytic activity of human neutrophils. Evid Based Complement Alternat Med. 2013;2013, Art. ID. 603634. p. 9.

34. Yuandani IJ, Ilangkovan M, Husain K, Chan KM. Inhibitory effects of compounds from Phyllanthus amarus on nitric oxide production, lymphocyte proliferation, and cytokine release from phagocytes. Drug Des Dev Ther. 2016;10:1935.

35. Roh K-B, Kim H, Shin S, Kim Y-S, Lee J-A, Kim MO, Jung E, Lee J, Park D. Anti-inflammatory effects of Zea mays L. husk extracts. BMC Complement Altern Med. 2016;16(1):298.

36. Lee SH, Soyoola E, Chanmugam P, Hart S, Sun W, Zhong H, Liou S, Simmons D, Hwang D. Selective expression of mitogen-inducible cyclooxygenase in macrophages stimulated with lipopolysaccharide. J Biol Chem. 1992;267(36):25934-8.

37. Xie W, Chipman JG, Robertson DL, Erikson R, Simmons DL. Expression of a mitogen-responsive gene encoding prostaglandin synthase is regulated by mRNA splicing. Proc Natl Acad Sci. 1991;88(7):2692-6.

38. Mohamed SIA, Jantan I, Haque MA. Naturally occurring immunomodulators with antitumor activity: an insight on their mechanisms of action. Int Immunopharmacol. 2017;50:291-304.

39. Baraf HS. Efficacy of the newest COX-2 selective inhibitors in rheumatic disease. Curr Pharm Des. 2007:13(22):2228-36.

40. Tham CL, Liew CY, Lam KW, Mohamad A-S, Kim MK, Cheah YK, Zakaria Z-A, Sulaiman M-R, Lajis NH, Israf DA. A synthetic curcuminoid derivative inhibits nitric oxide and proinflammatory cytokine synthesis. Eur J Pharmacol. 2010; 628(1-3):247-54.

41. Bertholet S, Tzeng E, Felley-Bosco E, Mauel J. Expression of the inducible NO synthase in human monocytic U937 cells allows high output nitric oxide production. J Leukoc Biol. 1999;65(1):50-8. 
42. Jung H-W, Seo U-K, Kim J-H, Leem K-H, Park Y-K. Flower extract of Panax notoginseng attenuates lipopolysaccharide-induced inflammatory response via blocking of NF-KB signaling pathway in murine macrophages. J Ethnopharmacol. 2009;122(2):313-9.

43. Oeckinghaus A, Ghosh S. The NF-KB family of transcription factors and its regulation. Cold Spring Harb Perspect Biol. 2009;1(4):a000034.

44. Kaminska B. MAPK signalling pathways as molecular targets for antiinflammatory therapy-from molecular mechanisms to therapeutic benefits. Biochim Biophys Acta. 2005;1754(1-2):253-62.

45. Laird MH, Rhee SH, Perkins DJ, Medvedev AE, Piao W, Fenton MJ, Vogel SN. TLR4/MyD88/PI3K interactions regulate TLR4 signaling. J Leukoc Biol. 2009; 85(6):966-77.

46. Medzhitov R. Toll-like receptors and innate immunity. Nat Rev Immunol. 2001;1(2):135.

47. Trinchieri G, Sher A. Cooperation of toll-like receptor signals in innate immune defence. Nat Rev Immunol. 2007;7(3):179.

48. Miller SI, Ernst RK, Bader MW. LPS, TLR4 and infectious disease diversity. Nat Rev Microbiol. 2005;3(1):36.

49. Seki E, Tsutsui H, limuro Y, Naka T, Son G, Akira S, Kishimoto T, Nakanishi K, Fujimoto J. Contribution of toll-like receptor/myeloid differentiation factor 88 signaling to murine liver regeneration. Hepatol. 2005;41(3):443-50.

Ready to submit your research? Choose BMC and benefit from:

- fast, convenient online submission

- thorough peer review by experienced researchers in your field

- rapid publication on acceptance

- support for research data, including large and complex data types

- gold Open Access which fosters wider collaboration and increased citations

- maximum visibility for your research: over $100 \mathrm{M}$ website views per year

At BMC, research is always in progress.

Learn more biomedcentral.com/submissions 